\title{
Reformers' unfulfilled promises: accountability deficits in Argentinean criminal courts
}

\author{
Pablo Ciocchini"
}

\begin{abstract}
Since the late 1980s, following the transition to democratic rule in Latin America, criminal courts all over the continent have been going through a process of continuous reform. Reformers introduced an adversarial-based procedural system, arguing that it would guarantee due process and greater transparency and accountability. However, in recent years, the emphasis of this reformist narrative has changed from expanding defendants' rights towards improving the efficacy of the system. This paper explores how the original principles of transparency and accountability have been upheld in criminal courts in one of the first areas of jurisdiction to implement those changes: the Province of Buenos Aires. Based on an analysis of data from forty-five in-depth interviews with key informants and court observations, this paper explores how the reforms developed a managerial rationality in criminal courts that may undermine the due process in Latin American jurisdictions that have undergone similar democratic reform processes.
\end{abstract}

\section{Introduction}

'Se vogliamo che tutto rimanga come è, bisogna che tutto cambi.' ${ }^{\text {I }}$ (Giuseppe Tomasi di Lampedusa, Il Gattopardo)

In the late I980s, most Latin American countries were in a process of transition towards democratic rule. After years of state terror, new governments sought to reform those state institutions that were perceived as being authoritarian. Because of their role in legitimating state violence, criminal courts and the police were generally considered a priority target of such reforms. The pattern across Latin American jurisdictions was similar: first, reforms aimed to 'de-militarise' and control the police ${ }^{2}$ and, second, they aimed to remove the roo-year-old criminal procedures codes (CPCs), which were perceived as being inquisitorial and were identified with an authoritarian culture, and replace them with adversarial- or accusatorial-based legal procedures that were claimed to be more transparent and efficient. ${ }^{3}$ Reforms in criminal courts were therefore meant to establish a 'due process model' that would provide much-needed control over a police force with a heavily authoritarian past.

* Department of Sociology, Social Policy and Criminology, University of Liverpool in Singapore, 529763, Singapore. E-mail: p.ciocchini@liverpool.ac.uk. I am especially grateful to Dr Dave Whyte for his comments on earlier drafts of this paper. I would also like to thank the anonymous reviewers for their insightful comments.

I 'If we want things to stay as they are, things will have to change.'

2 The militarisation of the police is a legacy of decades of authoritarian regimes in Latin America. See Glanc (2014), Hinton (2005) and Cruz (2015).

3 The distinction between inquisitorial and adversarial/accusatorial procedures has been widely used by Latin American scholars and politicians in their debates. See Ciocchini (20I4) and Duce and Pérez Perdomo (200I). This distinction is in line with the distinction between civil and common law. For an extensive critique of these categories, see the classic work by Damaška (I99I). See also Jimeno-Bulnes (2013). 
This paper explores the reforms of the criminal procedures implemented in the Province of Buenos Aires (PBA), Argentina, ${ }^{4}$ between the late 1980 s and late 20 Ios. Because of its characteristics, this case is an excellent example of challenges and outcomes that are common to these reform programmes in Latin America. The PBA's previous CPC had 'inquisitorial' features that were similar to the CPCs of other Latin American jurisdictions, since they were all rooted in the same Spanish tradition. Likewise, reform programmes implemented in most Latin American countries during this period were designed and promoted by the same actors (Duce, 2009; Langer, 2007). In 1996, the PBA became one of the first jurisdictions in the region to implement such reforms and only the second in Argentina to do so. It was also the third in Latin America to put the prosecution in charge of the investigation - one of the key features of the adversarial system. ${ }^{5}$ Consequently, the PBA's CPC has been in force for a longer period of time than those of other jurisdictions.

The reform's main goals, as established in the preliminary recitals of the new $\mathrm{CPC}$, were to improve transparency and accountability. These goals would be achieved by judging 'every crime ... at a public oral trial since this is the best method for finding out the truth and for meeting the needs of a republican form of government' (Preliminary Recitals Law no. I I,922, n.d.). The recitals stated that 'the public nature of hearings allows ... the community to oversee how trials are conducted (and) judges' behaviour and capacities' (Preliminary Recitals Law no. II,922, n.d.). Furthermore, they argued that judges would educate the 'public's perception of justice' through their sentences. It was claimed that public oral trials would improve the transparency of both the legal process and the preceding police investigation because they guarantee the 'fairest verdict ... due to the judge's proximity to the evidence and the parties' (Preliminary Recitals Law no. II,922, n.d.). While the number of public oral trials increased exponentially over this period, going from ninety-one verdicts passed in a public oral trial in 1995 to 4,557 in 2015 , this upsurge needs to be qualified. The number of cases taken to trial that year represents less than I per cent of the total reported criminal cases (719,728) and less than 2 per cent of those in which a suspect had been identified (384,382). Furthermore, almost three times as many verdicts were reached through plea bargaining (I 2,523) as through a public oral trial. ${ }^{6}$

The recitals recognised that, under the previous system, the investigation, though formally overseen by the judge, was in practice conducted by the police, and argued that an adversarial system using empowered public prosecutors would result in stricter control of the police investigation (Preliminary Recitals Law no. II,922, n.d.). However, in 20I5, twenty years after the reform, almost half of the criminal cases in which a suspect had been indicted were cases where the suspect was caught red-handed (I3,977). Those cases are disposed of through an expedited trial where the main evidence is the police report written at the point of the arrest. These figures, taken together with the high number of cases in which a suspect was identified but no indictment was made $(355,272)$, show worryingly poor investigative capacities on the part of the police.

4 The PBA is the largest and most populous province in Argentina: its 15,625,084 inhabitants represent 39 per cent of the country's population (INDEC, 20I0).

5 Four Latin American jurisdictions reformed their CPCs by putting prosecutors in charge of the investigation before the PBA: Peru (I99I), the Argentinean provinces of Córdoba (I99I) and Tucumán (I99I), and Guatemala (1993). However, the reform of the CPC in Peru was undermined by the political crisis that broke out in I992 (San Martin Castro, 1998). The Province of Córdoba’s CPC was not fully implemented until I998 (Mauri et al., 2013) and that of Tucumán offered a system in which judges decided whether to delegate the investigation to prosecutors.

6 The statistical information of criminal courts was provided by the Secretary of Planning of the Supreme Court of the Province of Buenos Aires. The information on reported case numbers was compiled by the prosecution service (Ministerio Público). 
A second wave of CPC reforms took place in Latin America in the first decade of the twenty-first century with the aim of strengthening the adversarial system. The explicit goal was to improve due process, and it was claimed that accountability and transparency would be improved by introducing pre-trial oral hearings, but the focus was on reducing backlog and offering shorter response times by increasing the efficiency of the court. This emphasis on efficiency, and particularly on shorter timeframes, was a regional expression of the global trend towards the acceleration of criminal court response (Eser, I996; Bastard et al., 2016). In 2004, the PBA became one of the first jurisdictions in the region to implement these reforms.7 However, as the statistics mentioned above show, these reforms did not reverse the use of alternatives to trial or the system's focus on simple crimes. In fact, it will be argued in this paper that, by focusing on efficiency, they consolidated that trend.

While reforms to implement adversarial systems had previously been implemented in several European countries (such as Portugal (Eser, I996) or Italy (Grande, 2000)), and more profound managerial reforms to reduce or eradicate backlog had been conducted in other jurisdictions (notably Singapore (Malik, 2007)), the reforms of the CPC in Latin America marked the start of a policy of democratisation by strengthening criminal justice institutions in the Americas (McLeod, 20I0).

In this paper, I seek to shed light on the actual impact that those programmes had on criminal courts in the PBA. My analysis focuses on three different but intimately connected changes in judicial practices: the shift from written procedures towards oral hearings, the introduction of alternatives to trial (particularly plea bargaining ${ }^{8}$ ) and the implementation of expedited trials and pre-trial hearings. I argue that these three shifts have produced a radical change that may have shortened the time required to dispose of a case but have not achieved the accountability they promised. The study is based on official statistics, observations of daily work in courts and prosecutors' offices and interviews with judges, prosecutors, defence attorneys and court officials.

The paper is divided into five sections. The first contains a description of the methodology used to collect data. The second describes the arguments put forward by reformers to support the replacement of written procedures with public oral trials. The following two sections explore the reasons behind this rather exceptional use of the public oral trial and the advantages of plea bargaining for the different parties involved, while the last section analyses the latest reform: the introduction of expedited trials and pre-trial hearings to speed up procedures. The paper concludes by reflecting on the implications of this analysis for other jurisdictions that have undergone a similar reform process.

\section{Methodology}

The research presented is based on fieldwork that I conducted between February and December 20IO in three judicial departments of the PBA. The fieldwork entailed forty-five semi-structured interviews with judges, prosecutors, defence attorneys and court officials, and observations of their interactions during the pre-trial and trial hearings in the courtroom. Although those hearings are meant to be public and are therefore open-access, police officers or court clerks nevertheless required that I explain my interest in the case to be granted access to the courtroom.

7 Pre-trial hearings and special procedures were first introduced in the first reform of the Chilean CPC in 2000 and in its subsequent modification two years later; see Preliminary Recitals Law no. 19,789. They were later implemented in the PBA (2004) and several other Latin American jurisdictions such as Costa Rica (2004), Colombia (2004-2008), the Argentina's Province of Córdoba (2006) and Peru (2008).

8 The 'juicio abreviado' is the local version of plea bargaining. See Section V for further details. 
I selected three of the PBA's twenty judicial departments for my observations, based on ease of access to the field while also seeking to cover the different social and political contexts in which the PBA criminal courts operate. The first judicial department selected was the one where pre-trial hearings and expedited trials were first introduced in 2004. It has since become a reference point for this second wave of reforms: during the implementation period (2005-2010), judges and court officials from other departments often came to observe hearings and be trained by members of this department. It is located in one of the largest cities of the PBA, Ioo kilometres away from the greater Buenos Aires. Most of its legal professionals who work in the judicial system were trained in the university based in that city. It is a well-known tourist destination and it has suffered in the last decades a rise in social inequality and shows high crime rates. The second judicial department is La Plata, the capital city of the PBA. The Supreme Court of the Province of Buenos Aires (SCBA) and the Court of Criminal Cassation sit in this department and consequently their practices tend to have more repercussions and influence on other judicial departments. The last is located in the south-east of greater Buenos Aires and is an area that suffers from social unrest due to extreme social inequality, an ever-growing population and low living standards due to a lack of public services. By including this department, I was able to verify that the practices I observed were not explained exclusively by the progressiveness of a given department (judicial department I) or its closeness to (and control of) higher courts (judicial department 2). The population of the three judicial departments selected represents 2I per cent (3,2I 7,49I inhabitants) of the total population of the PBA $(\mathrm{I} 5,625,084)$. The departments handled the I9.4 per cent of all cases in 2015 (Procuración General, 20I5). It is relevant to the general applicability of the results that there were no significant differences found in pre-trial and trial hearings between the three departments in terms of accountability and transparency.

I conducted interviews within these same judicial departments with the aim of providing a balanced perspective that included judges, prosecutors and defence attorneys in each location. To cover as broad as possible a scope of experiences, I selected two interviewees to represent each of the above roles in each judicial department (see Table I). The selection deliberately included some longer-serving interviewees who had entered the institution before the main reform of the CPC in 1996. The interviews were semi-structured, based on an interview guide consisting of a set of open-ended questions that covered the following areas: personal trajectories and key problems in the judicial institution; preference for the previous or current CPC (asked to those who had worked under both); relevance of court delay; personal views on plea bargaining, diversion, expedited trials, public oral trials, and pre-trial detention; and, lastly, training on personnel administration. The interviews ranged from thirty minutes to four hours in length and aimed to understand the interviewees' perspectives and reveal practices that remained hidden because they took place in spaces or situations that were not publicly accessible. None of the subjects I approached refused the invitation. When analysing their answers, I acknowledged their potential bias in favour of the system under which they currently operate. Nevertheless, they were all open to discussing their experiences and offered a critical perspective on the system. Their insights shed light on the logic behind some very complex legal strategies and revealed some hidden legal and organisational constraints that were not evident from an outsider's point of view.

All the interviews were conducted in Spanish and recorded in audio format, after which I transcribed and translated them.

\section{The reform of Latin American criminal procedure codes}

In the I980s, when most countries in Latin America started a transition from authoritarian regimes to democratic ones, a group of legal academics argued that reforms to criminal procedures were crucial to achieving much-needed transparency and accountability within the judiciary, and would thus 
Table I Interviews

\begin{tabular}{|c|c|c|c|c|}
\hline $\begin{array}{l}\text { Interviewee } \\
\text { no. }\end{array}$ & Role & Gender & $\begin{array}{l}\text { Entered service before } \\
\text { new CPC (1996)? }\end{array}$ & $\begin{array}{c}\text { Judicial } \\
\text { department }\end{array}$ \\
\hline I & Defence attorney (private) & M & Yes & 3 \\
\hline 2 & Chief departmental prosecutor & M & Yes & 2 \\
\hline 3 & Trial judge & M & Yes & 3 \\
\hline 4 & Chief departmental defence attorney & $\mathrm{F}$ & Yes & 2 \\
\hline 5 & Trial judge & $\mathrm{F}$ & Yes & I \\
\hline 6 & Defence attorney (public) & M & Yes & 2 \\
\hline 7 & Defence attorney (public) & M & Yes & 3 \\
\hline 8 & Second-instance prosecutor & $\mathrm{F}$ & Yes & 3 \\
\hline 9 & Prosecutor & M & Yes & 2 \\
\hline IO & Pre-trial judge & M & Yes & 2 \\
\hline I I & Second-instance judge & M & Yes & 2 \\
\hline I 2 & Second-instance judge & M & Yes & 2 \\
\hline I3 & Judge in charge of sentence enforcement & M & Yes & 2 \\
\hline I4 & District attorney & $\mathrm{F}$ & Yes & 3 \\
\hline I5 & Defence attorney (private) & M & No & 3 \\
\hline I6 & Second-instance defence attorney & $\mathrm{F}$ & Yes & 3 \\
\hline I7 & Defence attorney (public) & $\mathrm{F}$ & Yes & I \\
\hline I 8 & Pre-trial judge & M & Yes & 2 \\
\hline I9 & Prosecutor & $\mathrm{F}$ & Yes & 3 \\
\hline 20 & Prosecutor & $\mathrm{F}$ & No & 3 \\
\hline $2 \mathrm{I}$ & Trial judge & M & Yes & I \\
\hline 22 & Defence attorney (public) & M & Yes & 2 \\
\hline 23 & Prosecutor & M & Yes & 2 \\
\hline 24 & Pre-trial judge & M & Yes & 3 \\
\hline 25 & Legal secretary of the district attorney & M & No & 3 \\
\hline 26 & Defence attorney (public) & M & No & 3 \\
\hline 27 & Defence attorney (public) & M & No & 3 \\
\hline 28 & Defence attorney (private) & M & Yes & 2 \\
\hline 29 & $\begin{array}{l}\text { Director of the Office of Management of } \\
\text { Hearings (OGA for its initials in Spanish) }\end{array}$ & $\mathrm{F}$ & Yes & 2 \\
\hline 30 & $\begin{array}{l}\text { Director of the Office of Management of } \\
\text { Hearings (OGA for its initials in Spanish) }\end{array}$ & M & Yes & I \\
\hline $3 \mathrm{I}$ & Pre-trial judge & $\mathrm{M}$ & Yes & 2 \\
\hline 32 & Prosecutor & M & Yes & I \\
\hline 33 & Trial judge & M & Yes & 2 \\
\hline 34 & Trial judge & M & Yes & I \\
\hline 35 & Defence attorney (public) & $\mathrm{F}$ & Yes & I \\
\hline 36 & Prosecutor & M & Yes & 3 \\
\hline 37 & Prosecutor & $\mathrm{F}$ & Yes & I \\
\hline 38 & Pre-trial judge & M & Yes & I \\
\hline 39 & Pre-trial judge & M & Yes & I \\
\hline 40 & Trial court's law clerk & M & No & I \\
\hline $4 \mathrm{I}$ & Prosecutor & M & No & 3 \\
\hline 42 & Prosecutor & $\mathrm{F}$ & No & 3 \\
\hline 43 & Pre-trial judge & $\mathrm{F}$ & Yes & 3 \\
\hline 44 & Justice’s law clerk & M & Yes & 3 \\
\hline 45 & Justice’s Law Clerk & $\mathrm{F}$ & Yes & 3 \\
\hline 46 & Defence attorney (public)'s law clerk & M & No & 3 \\
\hline
\end{tabular}


strengthen the transition to democracy (Binder, I997; Hammergren, 2008; Langer, 2007, p. 634). Besides transparency and accountability, there was a strong consensus on the need to reduce the backlog in courts, which was a widespread problem throughout the region and weakened the legitimacy of judicial institutions (Duce, 2009). These scholars promoted the adoption of an adversarial-based CPC as a solution to these problems. They argued that replacing the old written procedures (which in some cases were even secret) with public oral trials and splitting the investigative and adjudicative tasks that the inquisitorial judge was in charge of between public prosecutors and judges would improve transparency and accountability and also the efficiency of the courts (Binder, I997; Duce and Pérez Perdomo, 200I; Maier, I993). Although the move towards an adversarial system can be seen as part of a global trend towards the Americanisation of justice, the early reforms in Latin America were inspired by the German CPC (StPO). Crucial to the spread of reforms were financial support from international organisations (notably USAID and the InterAmerican Development Bank) and a network of reformers (Langer, 2007). In 1996, the PBA became one of the first jurisdictions to implement these reforms and, by 20I0, more than fourteen countries in the region had followed suit.

However, there were serious shortcomings to this wave of reforms. Judges resisted the implementation of oral hearings in the pre-trial phase and continued to rely on written dossiers; prosecutors were unable to lead investigations and delegated that role to the police; and the backlog in courts was not reduced (Riego, 2002; Riego and Santalices Ariztía, 2003). These failures are partially explained, to use Langer's words, by the 'internal dispositions' of local legal professionals, who were predisposed to understanding criminal procedures and their roles within them in terms of the inquisitorial system in which they had been educated and socialised (Langer, 2004, pp. II-I2).

As a consequence, a second wave of reforms was instigated at the beginning of the twenty-first century. These implemented pre-trial oral hearings and differentiated adjunction, which remained the exclusive domain of judges, from the organisational management of courts, for which court managers were introduced. These reforms, inspired by the ones that had been implemented in Chile (Baytelman and Duce, 2003), were promoted by the Justice Studies Centre for the Americas (JSCA), an agency of the Organization of American States (OAS) that is based in Chile (Langer, 2007). Chile's model was perceived as highly successful in decreasing the pre-trial detention population and enhancing the efficiency of the criminal justice system (Tiede, 20I2, p. 66). The JSCA discourse placed strong emphasis on the connection between due process and judicial efficiency - a connection that justified the focus on managerial reforms (Vargas Viancos, 2003). Aware of problems that legal transplants had led to in the past, promoters of this second wave of reforms focused on changing practices rather than legislation by identifying incentives for judges and prosecutors to implement the new practices (REDEX, 20I0). Learning from the experience in Chile, they also favoured the progressive implementation of the new system in different judicial departments so that problems were identified and local solutions developed in the early stages of the process, rather than imposing abrupt, widespread changes (Baytelman and Duce, 2003). These reforms were implemented in the PBA in 2004 through a combination of legislative and organisational changes. The former included granting public prosecutors discretional power to cease prosecution and/or file the case when dealing with petty offences, and an expedited trial procedure was introduced for cases in which the defendant is caught red-handed. In terms of organisational changes, judges, prosecutors and public defence attorneys in one judicial department started to implement early hearings in the pre-trial stage to deal with these cases.

The results of this second wave of reforms vary by jurisdiction, but they are acknowledged as having been successful in implementing pre-trial hearings, reducing court backlogs and, in some jurisdictions, reducing pre-trial detentions (Duce et al., 2009). However, it should be noted that the 
vast majority of studies assessing the results were carried by the same organisation that promoted the reforms: the JSCA.

A recent study by Bergman and Langer based on surveys of convicts compares the old CPC operating in the national jurisdiction of Argentina ${ }^{9}$ with the PBA's CPC. The study showed there are no significant differences between the two systems in terms of due process: there are similar delays and numbers of defendants at the pre-trial stage, and both share a lack of transparency and accountability in the process, although the quality of investigations in the PBA may be marginally better (Bergman and Langer, 2015). Another recent study on the outcomes of reforms in Mexico that was based on the analysis of criminal cases confirms this trend and shows that the reduction in backlog has been achieved by focusing on cases in which defendants were caught red-handed by the police. These cases were dealt with through expedited trials without a proper oral debate to cross-examine the evidence gathered by the police (Fondevila et al., 20I6).

Nevertheless, none of these studies provides an empirical analysis of the day-to-day practices in criminal courts. This paper contributes to the debate and fills that gap by exploring the discourses and practices of judges, prosecutors and defence attorneys after the reforms. The following section describes these three groups' perspectives on public oral trials, plea bargaining, diversion and expedited trials, and contrasts them with statistical data and observations of courts' day-to-day work.

\section{The discourse on public oral trials}

My interviews with judges, prosecutors and defence attorneys revealed a strong consensus over the advantages of replacing written procedures with oral hearings in the criminal process. The interviewees praised the transparency and social impact that derive from the public nature of such trials and also argued that oral hearings were more efficient than written procedures. For example, a senior public prosecutor said that the oral hearings 'were synonymous with both openness and speed' (Interview 2). The interviewees strongly supported oral proceedings not just because of their public nature and efficiency, but also due to some of their indirect effects. One of the most praised of these was that they forced the main judicial officials to attend hearings and consequently prevented the widespread practice of delegating their duties to lower-ranking officials (Interviews 4, 5, 7, 8, 9, I0, II, I2, I3, I4 and I9). As one senior public defence attorney expressed:

'We were used to public defence attorneys staying in their offices focusing on public oral trials, leaving the whole first [pre-trial] stage in the hands of low-ranking officials, except for murder cases or others that we knew in advance would end in a trial no matter what .... The same was the case inside courts, where low-ranking judicial officials were in charge of deciding on requests for pre-trial detention orders ... [But now] we have the judge, the prosecutor, and the defence attorney seated together and they have to take responsibility and talk [in the hearing] $\ldots$ and the defendant is also present so he can listen to them and participate, and ultimately [judge] whether he is being well represented or not.' (Interview 4)

It is interesting to note that public oral trials were not a complete novelty for the PBA. They had already been available under the old CPC as an option for the defendant in homicide cases. ${ }^{\text {Io }}$ However, interviews revealed that the oral trial itself was a rather exceptional event. The

9 A new 'adversarial' CPC has been passed in 2014 but had not yet been put into practice as of late 2016.

Io Public oral trials in the PBA were first introduced in I9I5 as an option for defendants in cases involving serious crimes. In I986, shortly after the transition to democratic rule in Argentina, a legal reform made public oral trials mandatory in homicide cases. 
interviewees' claims are supported by statistical data provided by De Lázzari (I997). These show that, between I990 and I995, there were I,616,754 new criminal cases (that is, an average of 269,459 new cases per year) and that, every year, there were $15,78 \mathrm{I}$ verdicts on average, which means that less than 6 per cent of criminal cases reached a verdict. In addition, in 1995, only ninety-one of those verdicts were passed in a public oral trial, thus only 0.57 per cent of the verdicts of that year were passed in a public oral trial (0.034 per cent of the new criminal cases that year). After the reform of the CPC, the statistics published show that public oral trials were still rather exceptional. At the time the observations for this study were carried out, the official statistics provided by the SCBA stated that 4,557 public oral trials had taken place in 2015. This was a notable increment from the ninety-one passed in I995. However, considering that there were 719,728 new criminal cases in 20I5, then less than I per cent of the total cases reached a public oral trial. ${ }^{\mathrm{II}}$ As the experienced private defence attorney that criticised oral procedures said in the interview, in conclusion, only very serious crimes are taken to trial, as was the case before [the reform of the CPC]' (Interview 28).

Given the consensus among judges, prosecutors and defence attorneys on the benefits of public oral trials, it may seem surprising that they are in fact rarely used, but this is not actually different from the situation in other jurisdictions (Weigend, 2006; Bibas, 20I6; Mulcahy, I994). The rare use of public oral trials should come as no surprise: in the US, the jurisdiction that inspired these reforms, this was and continues to be the case (Langbein, I992; Dervan, 20II). Indeed, plea bargaining is used in more than 90 per cent of criminal cases in the US (Bibas, 20I6). Bibas lists a number of reasons that push defendants to plead guilty: 'the lawyers' incentives, the limits on discovery, the pressures of pre-trial detention, and the heuristics and biases that afflict decision making' (20I6, p. I060). While lawyers' incentives for avoiding uncertainty and reducing their workload and the pressures of pre-trial detention were certainly situations that I found to apply during my research in the PBA, this is not the case for others, such as limits on discovery, because of differences in process. Furthermore, factors related to chronic delays and a lack of police accountability have a significant impact on circumstances in Argentina but may not be so relevant in Anglo-American jurisdictions. It is important to note that reformers acknowledged this in the early stages of the reform process. Cafferata Nores (I989), a well-known Argentinean legal professor and a member of the government commission that promoted the reform of the CPC in I986, pointed out that the aim stated in the preliminary recitals of the I986 CPC project was not to prosecute every crime, because no jurisdiction was able to carry that out, but rather to provide clear criteria to ensure that the selection of which cases to prosecute was reasonable. However, in that project, only petty crimes (those punished with prison sentences of up to one year) were meant to be disposed of by alternatives to trial. The actual CPC passed years later widened the scope to include crimes punished with prison sentences of up to six years and, in the PBA, the universe of cases that could be disposed of through plea bargaining was later expanded to include those punished with prison sentences of up to fifteen years. It is thus debatable whether it should come as a surprise, fifteen years later, that only a minority of cases went to trial. However, reformers did not claim any responsibility for this development and they argued instead that public oral trials were not used due to the judiciary's lack of commitment to the reform, explaining their resistance to oral hearings as a way of maintaining the habit of delegating tasks to lower-ranking officials (Hazán, 2004; Binder, 2002). While interviews and observations

I I For comparative purposes, these figures are based on the total number of criminal cases, since the statistics of I 995 do not discriminate between cases in which a suspect has been identified and those without one. While there are significantly fewer cases in which a suspect has been identified (304,072 for 2015), the percentage of such cases that reach a public oral trial is still less than 2 per cent. 
confirmed that the practice of delegation existed, they also showed that there were several different reasons that drove judges, prosecutors and defence attorneys to avoid oral hearings.

\subsection{Grounding decisions properly}

While most interviewees (forty-three of forty-five) praised oral proceedings, many of them also highlighted that these did not provide enough time for developing sophisticated legal arguments to properly ground the decisions or appeals, such as those expected before the Court of Criminal Cassation (Tribunal de Casación Penal) (Interviews 4, 6 and I7). Oral hearings force judges, prosecutors and defence attorneys to act without having time to reflect on their decisions. The judges' expectations are that every judicial decision or request should not only be reasonable and in line with the law, but also properly justified. Such proper legal justification involves developing comprehensive legal reasoning and providing abundant evidence (i.e. jurisprudence and the established view among legal commentators or academics). To draft such justifications, attorneys and prosecutors need time to study the case, which immediate trails do not allow for. Moreover, most judges expect interventions to be formal written documents. The expectations are therefore enormous and only a few judges can live up to them. This was exemplified in a criminal judge's response to my question on whether he preferred the previous written procedures or the current oral hearings: ' $\ldots$ written documents are an essential part of controlling procedures, writing is the control itself' (Interview 3). But the consequence of these expectations around the formality and legal sophistication of interventions was a lack of interaction between prosecutors and defence attorneys during the pre-trial hearings and oral trials. I often observed that they came to the hearings having already discussed the outcome with the other party and the judge. There were no proper debates during the hearings, which instead entailed a performance in which prosecutors and defence attorneys reproduced debates that had taken place previously, behind closed doors. These re-enactments often involved their reading written files aloud in a monotonous tone of voice, and thus did not contribute to making the process transparent.

The introduction of oral hearings to a legal culture that was used to written procedures brought other problems. A senior private defence attorney (Interviewee I) pointed out during the interview that oral hearings left much to be desired in relation to the possibility of reviewing sentences. In Latin American jurisdictions, the right to a comprehensive appeal is firmly established, as is recognised in ACHR Article 8(2)(h) and IACHR jurisprudence, which understands this provision as the right to have access to a 'full review of the decision being challenged' (Herrera Ulloa V Costa Rica, 2004). This jurisprudence led Argentina's National Supreme Court (Casal, 2005) to pronounce on the extension of the right to appeal, stating that it includes the possibility of reviewing the facts of the case (Crespo, 20I0). This comprehensive appeal combined with the demands of a highly formalistic legal culture (the Court of Criminal Cassation was originally designed to only review issues of legal interpretation) has resulted in a delay of several years in hearing appeals. This delay has increased the risk of witnesses overlooking or forgetting the facts, and consequently prosecutors and defence attorneys produce extensive written records of oral hearings, foreseeing a future appeal hearing. This has further reinforced the written nature of local legal culture.

\subsection{Organisational difficulties}

Interviews with judges, prosecutors and defence attorneys shed light on the organisational reasons behind the avoidance of public oral trials. Some interviewees highlighted the organisational complexity that trials entailed (Interview 6), arguing that this complexity meant that the state was not able to bring every case to trial (Interviews 5, II, I2 and 27). They argued that public oral trials involved mobilising judges, judicial officials, prosecutors, defence attorneys and defendants for the pre-trial hearing, and then again for the proper trial hearing, which could last more than one day. Besides judges, prosecutors and defence attorneys, a number of other individuals needed 
to be brought to court for a trial to take place, including victims, witnesses, experts, police officers to maintain order in court and, in cases in which the defendant is detained, prison officers to oversee their custody. In the public trials I observed, court officials struggled to coordinate these actors. Hearings were often delayed because witnesses were absent or were delayed or even cancelled because the prison service failed to bring the defendant to court (the usual explanation given was the lack of available vehicles for transporting them there). Moreover, prosecutors and defence attorneys need to invest days and even weeks preparing for the trial (Interviews 6, I5 and I6). Public oral trials thus imply an onerous allocation of resources, particularly of judges', prosecutors' and defence attorneys' time, without any certainty as to whether the hearings will actually be held. The amount of time that a public oral trial entails functions as a strong incentive for actors to seek alternative mechanisms.

\subsection{Uncertainty of the result}

Another factor influencing the avoidance of public oral trials that emerged during the interviews and observations was the uncertainty over the outcome (Interview I7). This uncertainty was not only related to the difficulty of predicting how judges will interpret the evidence and the law, and how those interpretations will shape their decision, but was also connected to the unreliability of witnesses. It became very clear during my observations of trial hearings that, depending on the case, public prosecutors and defence attorneys were often anxious, fearing that witnesses would not appear in court even though it their legal duty to do so (in pre-trial hearings, summoning witnesses is rather exceptional). In several cases I observed, even police officers called to testify did not turn up or would arrive late; in some cases, judicial officials had to call them by phone to insist that they appear. ${ }^{\mathrm{I2}}$ Another dimension of the unreliability of witnesses' depositions also emerged: the unpredictability of their testimonies. Since most trials took place a long time after the actual crime was committed (between one and three years in ordinary cases and three to six months in red-handed cases), many witnesses struggled to remember details. During my observations, many seemed hesitant and even confused, and they often contradicted themselves. When this happened, either the public prosecutor or the defence attorney would immediately point out any discrepancies with their deposition during the investigation period and threaten to present charges in the case of a false statement. In one particular case, the witness begged the judges to read what he had testified four years ago because he could no longer remember what he had said. In concordance with these observations, a public prosecutor said to me that she had had to file three serious cases that she had been planning to bring to trial the year before because she was unable to locate the witnesses (who had previously declared before the police) or even the victim (Interview 20).

I 2 Whereas the defendant's non-attendance made it impossible to carry out the trial, judicial actors developed strategies for dealing with witnesses' absences. On several occasions, in order to continue with the trial, the parties would ask judges to accept the witnesses' written depositions made before the public prosecutor during the investigation as evidence in court. In the cases I observed, apart from a few in which the testimony seemed to be contested, the other party usually accepted the written deposition as evidence. Furthermore, these written depositions were already included in the case dossier. Reformers and most judicial actors ascribe the failure of the reforms that sought to replace written procedures to the ubiquity of these dossiers, which were usually read by the parties and the judges before the trial hearing. Instead of reading aloud the written deposition, either the prosecutor or the defence attorney would often merely indicate that it had been presented as evidence. Another strategy I observed once was to alter the order in which witness's depositions were presented so as to gain time in which to send police patrol cars to bring absent witnesses to court by force. But, even on that occasion, in a long trial that entailed four sessions over the course of ten days, only two of the six absent witnesses were found and brought to the court by the police. 


\subsection{Statute of limitations}

It is not uncommon that cases are dismissed because the statute of limitations has run out. This is partially a result of the court backlog and, as we have mentioned before, it was one of the arguments raised to promote the reforms. But, it is also a consequence of the strategies chosen by some defence attorneys. These defence attorneys will actively seek to delay the case before it is taken to trial by raising motions to the court and appealing the courts' decisions whenever it is possible (Interview 22). According to a defence attorney interviewed, this strategy is mostly used in cases of small offences because the statute of limitations period is proportional to the potential prison sentence faced by the defendant (and therefore it is easier to exceed the time period) or in most serious cases when the defendant has not been detained or was granted home detention (Interview 6).

In conclusion, the public oral trial constituted an organisational challenge to criminal courts and a risk to the parties. They were thus widely avoided by judges, prosecutors and defence attorneys and only used in exceptional cases. As a consequence, public oral trials provide very little transparency and accountability in practice. However, although they are a rare event in practice, oral trials are a potential source of legitimacy for courts and enable the use of alternative mechanisms for disposing of cases that might otherwise lead to a questioning of the very purpose of criminal courts. The next section scrutinises these alternative mechanisms.

\section{From compulsory prosecution to bargaining justice}

The most widely used alternative mechanisms to dispose of cases are diversion ${ }^{\mathrm{I} 3}$ and plea bargaining. ${ }^{I 4}$ The problem they present is that, far from improving the democratic nature of criminal courts by offering more transparency and accountability, they avoid a proper discussion of the evidence gathered by the police and consequently legitimise police intervention.

The implementation of diversion in the PBA entails a series of problems, ${ }^{15}$ but plea bargaining is by far the most problematic mechanism. The Anglo-American literature has documented and commented on a series of problematic issues that have emerged from the use of plea bargaining in America and England (Langbein, I978; Mather, I979; Mulcahy, I994; Feeley, I997; McCoy, 2005). While critics disagree on some aspects, most concur on a series of complications that derive from plea bargaining, including its extortive nature and the excessive reliance on the discretion of court officials without proper accountability mechanisms. Similarly, it has been documented in other jurisdictions that judges, prosecutors and defence attorneys favour the practice of plea bargaining by arguing that it is based on the defendant's will, it avoids unnecessary trials, consequently reducing workloads, and that the defence attorney's advice counteracts its potentially extortive nature (Roach Anleu and Mack, 200I; Mulcahy, I994; Cheng, 2014).

The mechanism of plea bargaining in civil law jurisdictions varies significantly. To use Langer's (2004) metaphor, in each jurisdiction, it has been translated into the local procedural language.

I3 'Suspensión del juicio a prueba', the local name for diversion, used to be referred to as 'probation' by local legislators and is still called this by local actors, although it is actually similar to what is referred to as diversion in the US, because it suspends the trial and not the sentence.

I4 Although twelve interviewees (2, 7, I4, I5, I 7, I8, I 9, 25, 32, 34, 35 and 36) mentioned mediation as an option when I asked about alternative mechanisms, they talked about it as an exceptional measure. Interviewee I 9 stated that, at that time (2010), she perceived that defence attorneys' attitudes towards mediation were changing, in that they were becoming more open to using it. Similarly, Interviewee 2 said that mediation was increasingly used to 'filter out' 'real' criminal cases.

I5 The lack of control over diversion programmes and the fact that defence attorneys resort to these to reduce their workload create a 'net-widening' effect that results in the stigmatisation of defendants who fail to comply with diversion programmes and thus face harsher sentences in the future. 
However, Langer (2004) also argues that the 'translation' of plea bargaining in Argentina has been faithful to the American original. However, in the Argentinean version, the agreement reached in a plea bargaining only imposes a limit on the judge: she/he cannot sentence more severely than has already been agreed between defendant and prosecutor, but she/he can always pass a more lenient sentence or even acquit the defendant if she/he considers there is not enough evidence. Other relevant differences pointed out by Langer between the American and Argentinean systems are: the timescale of the agreement is subject to limitations (thirty days before trial, in the PBA) and that, in cases with multiple defendants, the mechanism can be applied only if accepted by each defendant (Langer, 2004). While what Langer is describing is plea bargaining in the national jurisdiction, the situation is very similar in the PBA. If anything, the implementation in the PBA is even more faithful to the American plea-bargaining system because, in cases of multiple defendants, it does not require every defendant to accept the agreement. Reflecting on plea bargaining in America, Langer (2006) has argued that the key distinction to be made is between cases in which plea bargaining takes place under coercion. He argues that coercion exists in three cases: when public prosecutors charge defendants in weak cases where no reasonable jury could find them guilty, when they overcharge defendants or when defendants face excessively harsh sentences if they choose to go to trial. It should be noted that, in the case of the PBA, public prosecutors must disclose the evidence gathered and the judge must evaluate that evidence in her/ his verdict. Consequently, coercion as per Langer's terms is rather limited in local plea bargaining. However, as is shown in the following subsections, in practice, judges sentence according to the agreement without a thorough examination of the evidence. Furthermore, in the context of the $\mathrm{PBA}$, coercion is also the result of the widespread use of pre-trial detention (Bergman and Langer, 20I5) and the delay defendants face if they choose to go to trial.

\subsection{The normalisation of plea bargaining}

In the three judicial departments in which fieldwork was conducted, there are almost three times as many verdicts given through plea bargaining as those passed after public oral trial (see Figure I).

During my fieldwork, I observed several pre-trial hearings that ended in plea-bargaining processes and, in most cases, judges would sentence in line with that agreement. While some judges would take the time to read through the dossier before giving a verdict, identifying the potential evidence for the case collected by the prosecutor and listing this in their verdict, other judges would merely refer to the evidence indicated in the dossier. In the cases I observed, judges sentenced in keeping with the

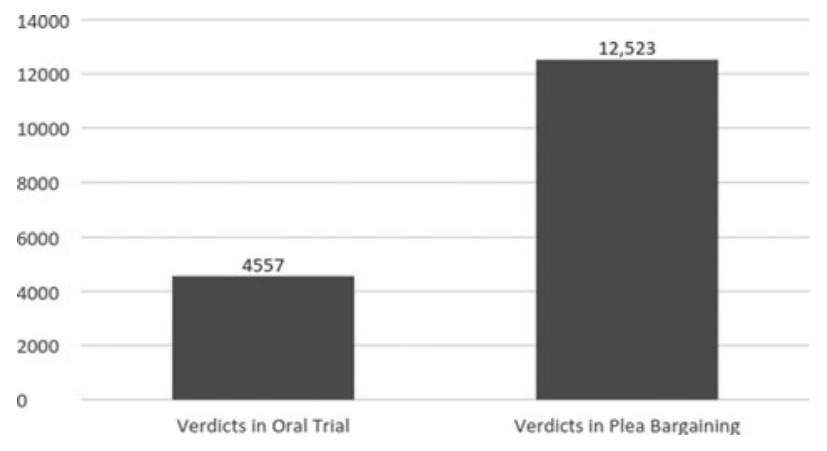

Figure $\mathbf{r}$

Total verdicts in public trial vs. total verdicts in plea bargaining in the three judicial departments studied 
agreement reached by the parties, and the focus of their referring to the evidence seemed to be formally justifying the sentence.

The judges, prosecutors and defence attorneys I interviewed justified plea bargaining on the basis that defendants can always decide to take their case to public oral trial, which is in line with the official discourse (Interviews 4, 8, 9 and 36). Plea bargaining is therefore presented as an alternative to the normal way of disposing of a case and it should be an exceptional mechanism for cases in which the facts are not contested. However, that is not how plea bargaining works in reality in the PBA. Indeed, it rapidly became, together with diversion, the normal procedure for disposing of criminal cases. In the case of the PBA, twenty-five of the interviewees argued in favour of the use of plea bargaining, eleven of them objected in some way to the mechanism but conceded that it was necessary to prevent law courts from collapsing and only three of the interviewees, all defence attorneys, were completely opposed to the use of plea bargaining (Interviews I, 22 and 28). ${ }^{\mathrm{I}}$ The objections that they and the other dissenting interviewees presented can be classified either as objections either against the extortive nature of the process or against the economic logic that underlies the choice of sentence. ${ }^{\mathrm{I7}}$

\subsection{The extortive nature of plea bargaining}

The main objection expressed against plea bargaining by judges, prosecutors and defence attorneys is that negotiation essentially takes place under threat and can easily become extortive (Interviews I, II, I2, I6, 2I, 22, 23, 24 and 25). As one senior private attorney argued,

'if speeding up the procedure means resorting to plea bargaining, where is the speed in that? Speeding up then means getting a sentence fast by restricting the right to defence .... When people talk to me about speedy procedures that involve abolishing any type of legal protection and in which defendants that must negotiate while under detention, it looks to me more like extortion than speed.' (Interview I)

However, several judges, prosecutors and defence attorneys pointed out that the introduction of expedited trials reduced the extortive character of plea bargaining (Interviews 7, I2, I3, I6, I9, 23 and 26). That is because, in a regular criminal procedure, the date of trial is uncertain. Compared with the possibility of waiting years under detention for a trial, plea bargaining implied the possibility of establishing a known detention period with a chance for seeking early release once the accused had served two-thirds of the prison sentence, which often meant immediate release, given the length of time that they had already been detained. Under these conditions, plea bargaining paradoxically meant that the defendant would agree on a prison sentence in order to be released. That is why plea bargaining was referred to in courts jargon as habeas corpus sentencing' (Interviews 7, 23 and 3I).

\section{3 'Give and take'}

Public prosecutors and defence attorneys showed opposed perceptions on the economic rationality that drives case disposal and punishment promoted by plea bargaining and diversion. Whereas law and legal doctrine traditionally prescribe that the sentencing criteria are the particularities of each case, under diversion and plea bargaining, case-load and disposal opportunities are equally

I6 Six interviewees did not express their opinion on the use of plea bargaining. In some cases, it was because they performed administrative rather than legal tasks (Interviews 29 and 30) and, therefore, did not have experience or expertise on the issue.

I7 These are consistent with the criticisms identified in other jurisdictions as documented in Langbein (I978) and Mulcahy (I994). 
relevant or even more so. It could be argued that there was always some level of 'negotiated expectations' between the different participants at court. But interviewees talked about this economic rationality as something new that was different from the law itself. This 'novelty' can be perceived in the statements of those who rejected it:

'Plea bargaining goes against the Constitution. It is extortive, it completely delegitimizes the criminal procedure ... and it also delegitimizes the punishment. Because plea bargaining is "give and take", it delegitimizes punishment, the sentence loses its value and its meaning: two, three, four, or five months [of prison] are the same thing, the only relevant issue is closing the case.' (Interview 22)

It is also evident in the words of those who would like greater freedom to bargain:

'I would like to have more options, but I know that it is dangerous or perhaps it's better to say that it's risky to give such power to people who are not prepared to use it. In a criminal case, flexibility or the possibility of bargaining are appealing to me (I'm talking about being able to negotiate on decent terms, in the sense of being able to negotiate penalties) as a way of obtaining information from the defendant (like in the American system). However, I am aware that putting that kind of power in the hands of lunatics, or people who aren't qualified to handle it, could become a danger.' (Interview 32)

This rationality requires prosecutors to adjust the punishments they are seeking to defendants' expectations, which are, in turn, based on the magnitude of the sentences imposed by judges in public oral trials. The 'novelty' of this can also be recognised in the absence of inexperience regarding how to develop a reasonable criterion for negotiate. As a prosecutor told me, when she was first appointed, she was very tough, so no defence attorneys were willing to bargain with her and instead preferred to go to trial. So she said to herself, 'I have to change because I am not in line with what the system is offering; I need to offer more sensible sentence agreements' (Interview I9).

A dangerous aspect of this 'give and take' is that it loses sight of the goal of criminal procedure, as Interviewee 22 mentioned above. This is perhaps why unscrupulous defence attorneys use plea bargaining to reduce their workload, according to Interviewee 28 : '.. you are at a real risk with lawyers that are lazy, dishonest, unethical, and incompetent, that bargain any case. How dare they plea bargain in such cases [where you have elements to prove your client's innocence]?' (Interview 28).

\subsection{Plea bargaining as a defence strategy}

Despite these problematic aspects, plea bargaining should not be described merely as capitulation on the part of the defendant or defence attorney. Defence attorneys have appropriated plea bargaining in their defence strategies, exploiting its benefits and even altering its original use. The law is not simply an instrument that mediates human interactions, but is itself a manifestation of those interactions. The use of plea bargaining would be better understood as an arrangement between different judges, prosecutors and defence attorneys that is reconfirmed in each interaction but is always open to change. Rather than viewing plea bargains as fixed arrangements, they should be analysed as being conditionally dependent upon the relations of force that underlie each one. A public defence attorney described two different 'alternative' uses of plea bargaining by the defence to me (Interviewee 7). First, in cases in which they think the evidence is not strong, the defence will present two pleas to the judge: one that has been agreed upon with the public prosecutor and an alternative plea for a less serious charge that has not been previously discussed with the public 
prosecutor. Since plea bargaining in Argentina only fixes the maximum potential sentence while keeping the judge's power to decide over the case intact in all other ways, the alternative plea seeks to persuade the judge to sentence more leniently than the first plea presented. Moreover, there is always the possibility of the judge acquitting the defendant, even if an agreement was presented.

The other strategy that this interviewee talked about was appealing the sentence based on the agreement reached (Interview 7). In the Argentinean legal system, there is a prohibition of reformatio in peius, which means that the defendant's appeal can never change the verdict or sentence to his/her detriment. Consequently, defence attorneys would agree on a particular charge and sentence with public prosecutors, then, after the judge's sentence, they would seek to find arguments that might lead to the annulment of the case, which could range from formal mistakes to more substantive issues such as police misconduct during the investigation. This strategy makes sense because plea bargaining leaves no space for a proper debate on the evidence, so it is only through appeals that such evidence can be disputed. According to a defence attorney and prosecutor before the Court of Criminal Cassation, this defence strategy is common but it is contested from inside the judiciary (Interviews 8 and I6). The public prosecutor described this strategy as disloyal and even the defence attorney before the Court of Criminal Cassation confessed she found it very confusing initially, even though her position means that she is responsible for following the appeal led by a first-instance defence attorney (Interviews 8 and I6).

In conclusion, the introduction of bargaining justice (which aimed to increase efficiency by reducing court backlog) has enabled the system to sentence defendants without a proper debate over the evidence gathered by the police. By doing so, it has greatly reduced the transparency and accountability of the criminal process.

\section{Bringing the trial into the pre-trial hearing}

In 2004, a second wave of reforms started the progressive introduction in each judicial department of expedited trials and early pre-trial hearings for cases in which the defendant was caught red-handed. The implementation process was only finished in 20I0. As was stated in the introduction of this paper, these procedures had significant impact because cases involving defendants caught redhanded represented a sizable proportion of the cases with a 'known perpetrator'.

With the alleged purpose of bringing accountability and efficiency to the pre-trial stage, these mechanisms focused resources on the simplest crimes and promoted early alternative mechanisms to dispose of them. However, by doing so, they consolidated the role of criminal courts as legitimisers of police interventions into everyday petty crimes. These mechanisms were successful in indirectly inducing judges, prosecutors and defence attorneys to behave in a particular way, or, to use's Foucault's terms, 'to conduct conducts' by creating favourable conditions for promoting early negotiations between the parties and, consequently, settling the case before the pre-trial judge. They introduced an early pre-trial hearing that should take place before the fifth day of detention and they established a forty-day limit for the investigation to be conducted. Before the fortieth day, another hearing should take place in which the public prosecutor decides whether or not to take the case to trial. This time span contrasts notably with the ten months allowed to regular procedures. The general success in reducing the time it took to deal with a case (Palmieri et al., 2004; Hazán and Riego, 2007; Hazán and Iud, 2010) had dramatic consequences in cases of plea bargaining. Even those judges, prosecutors and defence attorneys that criticised plea bargaining argued that expedited trials made the process fairer (Interviews 7, 2I and 23) because defendants were affected not only by the possibility of a harsher sentence during trial, but also by the length of time that they would have to spend under detention until the trial took place. By 
reducing the waiting time for the trial, this last coaction was removed and thus there was no need to use plea bargaining as 'habeas corpus sentencing' (see Section 5.2, above).

The interviews revealed that judges and prosecutors strongly supported this system, although the defence attorneys did not. Their objections were based on the system's focus on simple street crimes and the power of the police narrative in shaping those cases. Furthermore, although expedited trials were presented as a necessary way of relieving part of the workload of trial courts and public prosecutor's offices so that they could focus on more complex cases, there is an overall consensus that this did not actually happen - instead, the system focused its resources on the simplest crimes.

\subsection{Focus on simple crimes}

One of the main arguments used to support different techniques that gave more discretionary power to public prosecutors so they could file some cases and bargain in others was that it would free up resources for prosecuting more serious and complex cases (Preliminary Recitals Law no. I 3,I83, n.d.). However, interviewees argued that, while trial courts were indeed released from a significant workload and the backlog they suffered decreased dramatically (Interviews 2, 5 and 33), this relief did not lead to greater prosecution of serious cases (Interviews I2, 3I and 32). This is consistent with the findings of Bergman and Langer (2015) in the PBA and Fondevila et al. (2016) in Mexico.

This focus on simple crimes can be explained mainly by two factors. First, the incapacity of police to investigate complex cases (and of prosecutors to control and direct them). This is consequence of a broader lack of control over the police and it will be discussed in depth below in Section 6.3.

Second, the focus on expedited trials with their short deadlines force judges, prosecutors and defence attorneys to continually devote time to these cases, or, as one interviewee said:

'I mean, you dispose of cases faster but the consequence is that you are away from your desk most of the time, and that's where you need to be to work on the most serious cases; I spend all my time in [expedited trial] hearings, here and there.' (Interview I7)

Expedited trials increased the criminal courts' capability for dealing with simple cases or, as a defence attorney bluntly put it, 'the expedited trial is very useful for straightforward cases, where petty crimes are involved' (Interview 35). For example, a private defence attorney told me how surprised he and his client were when they were called to a court hearing and the judge decreed diversion after a minor discussion with a police officer. According to the attorney, the courts tend to deal with such cases through inaction: they wait until the time specified for those offences in the statute of limitations has passed (Interview I5).

These new capabilities for dealing with simple cases are revealed in the statistics received from the SCBA on expedited trials. They showed that, in 20I 5, I 4.9 per cent of the total judicial resolutions made at the pre-trial stage then were diversion and 16.5 per cent were plea bargaining. This means that, in the forty days since the defendant was detained, 3I.4 per cent of cases were disposed of using those mechanisms. However, as has been shown in the previous sections, those cases are five times more likely to end in diversion or plea bargaining than to be disposed of in a trial hearing. Due to this perceived increased capacity for processing more cases, expedited trials were met with strong criticism from judges, prosecutors and defence attorneys who espoused pro-human rights discourses. One defence attorney called them the 'McDonald-isation' of justice and argued they were driven by a punitive logic (Ganón, 2008). One interviewee put it in very simple terms:

'The number of sentences has increased, and that means that what was previously a pre-trial detention is now a sentence. But the fact of the matter, which is that people are being locked up, has not changed, only the label has changed: it used to be a pre-trial detention and now it is a sentence.' (Interview 22) 


\subsection{Dangerous accumulation of power in the hands of the pre-trial judge}

One of the interviewees highlighted the controversial sentencing powers given to pre-trial judges when an agreement has been reached:

'In my opinion, this has to change ... it is unnecessary for pre-trial judges to pass sentence in cases with a plea agreement ... I mean, the judge that was in charge of overseeing the investigation, the one that decided on the defendant's pre-trial detention and so on is also the one that passes sentences in cases when the parties have reached an agreement ... [This measure] was useful for taking the pressure off the system initially, but if we want an ideal system, the case should be decided by another pre-trial judge who has not been involved in the case before.' (Interview 4)

Thus, paradoxically, expedited trials, which were promoted as the strengthening of the adversarial system due to their emphasis on oral hearings, have ended up creating quasi-inquisitorial judges by giving sentencing powers to the pre-trial judge. The same judge decides over the legality of the arrest made by the police; whether to release the defendant or to maintain him/her on pre-trial detention; whether he/she should grant arrest, search or wiretaps warrants requested by public prosecutors; and whether there are grounds for the public prosecutor's request to take the case to trial. He/she can decree diversion and now may also pass sentence when a plea-bargaining agreement has been reached by the parties. To gauge the magnitude of the power that has been accumulated in the name of efficiency, the high proportion of cases settled either by diversion or plea bargaining should be borne in mind, as has been indicated above.

\subsection{Police impunity}

Through expedited trials, criminal courts have their attention on crimes in which the defendant has been caught red-handed (Interviews 7 and I9). By definition, this means the defendant has been identified and arrested by the police and that the offence is a non-sophisticated street crime. Criminal courts thus invest most of their resources in judging cases brought by the police in which a defendant has been arrested and accused of having committed a simple crime. According to some judges, prosecutors and defence attorneys, expedited trials reduce the defendant's chances of discussing the charges presented and the evidence gathered by the police by putting pressure pressing on judges, prosecutors and defence attorneys to reach a prompt agreement (Interviews 26 and 27). This is even more serious since police conduct, and particularly the police force's capacity to investigate, was contested by most of the judges, prosecutors and defence attorneys interviewed. Examples of this mistrust include the following statements:

'I am not aware of any proper investigation being carried out by the police. I mean, the police do not investigate at all, they bring whatever they have stumbled across.' (Interview 2I)

'... most cases that enter into the criminal justice system are not the product of a prior investigation but of the police happening across a crime.' (Interview 7)

'... on many occasions, the police set up a case and use the expedited trial system, arguing that there are witnesses when in fact this is a lie.' (Interview 27)

'I think the police are monsters. I would never try to put the police back on track. It would be like trying to stop the Titanic from sinking by bailing it out with a bucket. ... I try to work autonomously. I expect nothing from the police.' (Interview 20) 
'Don't forget that the police are important players in the criminal justice system. If you follow them blindly, you don't get anywhere. The help they provide is insignificant because they are focused on political matters. What I am trying to say is that when the criminal justice system goes in one direction and crime and security politics go in the opposite one, the police do not work properly. ... The police avoid getting involved, they prefer to avoid any potential complications, they don't do any work, and the only criminals that they bring in to see the public prosecutor are ones that they have bumped into on the street.' (Interview 32)

Therefore, by focusing on reducing the waiting time for simple crimes, expedited trials introduce incentives for settling cases and reducing the space for defendants to contest police interventions that support those cases. The consequence is improved capability on the part of the police to prosecute unsophisticated street crimes at the expense of a more transparent process that could improve the accountability of both the police and criminal courts.

\section{Conclusions}

Reforms to the criminal courts in the PBA (and in Latin America as a whole) encouraged the introduction of public oral trials and the adversarial system, which, it was argued, would improve the transparency, accountability and efficiency of the criminal courts and thus of the criminal justice system. However, the analysis we have carried out of the practices chosen by prosecutors, defence attorneys and judges has shown that these reforms heavily favoured managerial concerns, namely reduction of courts' backlog, over an improvement in transparency and accountability. The public oral trial, and oral hearings in general (e.g. pre-trial and appeal hearings), were advocated as crucial to increase transparency and accountability but, in practice, the reforms promoted the use of alternative mechanisms (notably plea bargaining) over public trial to dispose of cases. By doing so, hearings were no longer a mechanism of control, but an opportunity to push parties to make a deal. Consequently, just as inquisitorial judges formerly made decisions based on the evidence collected by the police without much opportunity for the defence to contest such evidence, under the current system, the vast majority of cases are solved through a deal made on the basis of police narrative without any debate over the evidence collected. The result is a general lack of accountability in a system that processes cases faster by focusing on simple street crimes and is based on police accusations. This research thus reveals that, if the aim of reforms was to improve transparency and accountability, as reformers and politicians have claimed, then it was not enough to merely replace the inquisitorial system with an adversarial one. The numerous problems related to the conduct of public oral trials, police impunity and its lack of capacity to conduct complex investigations, together with the incapacity of prosecutors to control and direct the police, should have been addressed to achieve that promised accountability and transparency. But, as in the case studied, instead of dealing with these problems, the reforms incentivised prosecutors to focus on simple cases and to deal with them with alternative mechanisms to reduce courts' backlog. As a result, their mere accomplishment was to consolidate a justice system based on a questioned police force paving the way for serious miscarriages of justice.

\section{References}

Bastard, Benoit, delvaux, David, mouhanna, Christian and schoenaers, Frédéric (20i6) Justice ou précipitation: l'accélération du temps dans les tribunaux. Rennes: PUR.

BAYTELman, Andrés and DUCE, Mauricio (2003) Evaluación de la reforma procesal penal: estado de una reforma en marcha. Santiago: CEJA. 
BERGMAn, Marcelo and LANGer, Máximo (2015) 'El nuevo código procesal penal nacional acusatorio: aportes empíricos para la discusión en base a la experiencia en la Provincia de Buenos Aires', Revista de derecho procesal penal I: 5I-80.

BIBAs, Stephanos (2016) 'Designing Plea Bargaining from the Ground Up: Accuracy and Fairness without Trials as Backstops', Faculty Scholarship. Available at: 〈http://scholarship.law.upenn. edu/faculty_scholarship/I644> (accessed 6 November 2017).

BINDER, Alberto M. (I997) Política criminal: de la formulación a la praxis. Buenos Aires: Ad Hoc.

BINDER, Alberto M. (2002) 'Los oficios del jurista: la fragmentación de la profesión jurídica y la uniformidad de la carrera judicial', Sistemas judiciales I: 34-53.

CAFFERATA NORES, José (I989) 'Legalidad y oportunidad; criterios y formas de selección' in Symposium internacional sobre la transformación de la justicia penal en la República Argentina. Buenos Aires: Presidencia de la Nación Argentina, 2 I-28.

CASAL, Matías Eugenio y otro s/ robo simple en grado de tentativa (2005) Supreme Court of Argentina, Case I68I (Fallos, 328:3399), 20 September 2005.

CHEng, Kevin K.-Y. (2014) 'The Practice and Justifications of Plea Bargaining by Hong Kong Criminal Defence Lawyers', Asian Journal of Law and Society I: 395-4I 2.

ciocchins, Pablo (20I4) 'Campaigning to Eradicate Court Delay: Power Shifts and New Governance in Criminal Justice', Crime, Law and Social Change 6I: 6I-79.

CRESPO, Álvaro E. (2010) 'El nuevo diseño de la casación penal', Revista electrónica Derecho Penal Online. Available at: 〈http://derechopenalonline.com/el-nuevo-diseno-de-la-casacion-penal/〉 (accessed 24 November 2017).

CRUZ, José M. (2015) 'Police Misconduct and Political Legitimacy in Central America', Journal of Latin American Studies 47: 25I-283.

DAMAŠKA, Mirjan (I99I) Faces of Justice and State Authority: A Comparative Approach to the Legal Process. Hartford: Yale University Press.

DE LÁZzARI, Eduardo (1997) 'El ministerio público fiscal y la reforma procesal’ in Carlos Chiara Díaz (ed.) Código procesal penal de la Provincia de Buenos Aires comentado. Buenos Aires: Rubinzal, 55-74.

DerVAn, Lucian E. (20II) 'Overcriminalization 2.0: The Symbiotic Relationship between Plea Bargaining and Overcriminalization', Journal of Law, Economics and Policy 7: 645-655.

DUCE, Mauricio (2009) 'Reforma de la justicia penal en América Latina: Una perspectiva panorámica y comparada, examinando su desarrollo, contenidos y desafíos', UDP Public Policy Series - Working Papers 3: I-39.

DUCE, Mauricio and PÉREZ PERDOMO, Rogelio (200I) 'Seguridad, ciudadanía y reforma de la justicia penal en América Latina', Boletín Mexicano de Derecho Comparado XXXIV: 755-787.

DUCE, Mauricio, fuentes, Claudio and RIEgo, Cristián (2009) 'La reforma procesal penal en América Latina y su impacto en el uso de la prisión preventiva' in Cristián Riego and Mauricio Duce (eds) Prisión preventiva y reforma procesal penal en América Latina. Santiago: CEJA, I3-72.

ESER, Albin (1996) 'The Acceleration of Criminal Proceedings and the Rights of the Accused: Comparative Observations as to the Reform of Criminal Procedure in Europe', Maastricht Journal of European and Comparative Law 3: 34I-370.

FEeLEy, Malcolm (1997) 'Legal Complexity and the Transformation of the Criminal Process: The Origins of Plea Bargaining', Israel Law Review 31: I83-222.

fondevila, Gustavo, langer, Máximo, Bergman, Marcelo, vialta, Carlos and mejía, Alberto (20I6) ¿Cómo se juzga en el Estado de México? Una radiografía de la operación del sistema de justicia penal acusatorio. Mexico City: CIDE.

GANón, Gabriel (2008) 'LLa "macdonalización" del sistema de justicia criminal? La aceptación improvisada de los paquetes de reforma judicial para el tercer milenio' in Roberto Bergalli, Iñaki Rivera Beiras and Gabriel Bombini (eds) Violencia y Sistema Penal. Buenos Aires: Del Puerto, 237-265. 
Glanc, Laura (2014) 'Caught between Soldiers and Police Officers: Police Violence in Contemporary Argentina', Policing and Society 24: 479-496.

GRANDE, Elisabetta (2000) 'Italian Criminal Justice: Borrowing and Resistance', American Journal of Comparative Law 48: 227-259.

HAMmergRen, Linn (2008) 'Twenty-Five Years of Latin American Judicial Reforms: Achievements, Disappointments, and Emerging Issues', Whitehead Journal of Diplomacy and International Relations 9: 89-104.

HAzÁn, Luciano (2004) 'Entrevista a Roberto Berizonce: "La oralidad no es para jueces cómodos, sino al revés"', Sistemas judiciales 7: 8-I6.

HAZÁn, Luciano and IUD, Alan (2010) 'Informe de evaluación del proceso de fortalecimiento del sistema acusatorio en la Provincia de Buenos Aires - plan de flagrancia' in Primer encuentro nacional Redex Argentina. Córdoba: Advocatus, I6 I-235.

HAZÁn, Luciano and RIEGO, Cristián (2007) 'La oralidad en las etapas previas al juicio: la experiencia de Mar del Plata' in Cristián Riego (ed.) Reformas procesales en América Latina: Resultados del proyecto de seguimiento, IV Etapa. Santiago: CEJA, 255-294.

herRera UlLOA V COSTA RICA (2004) Preliminary Objections, Merits, Reparations and Costs, IACHR 3, IACHR Series C No I07, IHRL I 490 (IACHR 2004), 2 July 2004.

HINTON, Mercedes S. (2005) 'A Distant Reality: Democratic Policing in Argentina and Brazil', Criminal Justice 5: 75-100.

INDEC (20IO) 'Cuadro Pi-P. Provincia de Buenos Aires. Población total y variación intercensal absoluta y relativa por partido: Años 200I-20Io’. Available at: <http://www.indec.gov.ar/ftp/censos/20Io/ CuadrosDefinitivos/Pr-P_Buenos_Aires.pdf $>$ (accessed 6 November 20I7).

Jimeno-bulnes, Mar (2013) 'American Criminal Procedure in a European Context', Cardozo Journal of International Comparative Law 2I: 409-459.

LANGBeIn, John (I978) 'Torture and Plea Bargaining', Faculty Scholarship Series. Available at: <http:// digitalcommons.law.yale.edu/fss_papers/543> (accessed 6 November 2017).

LANGBeIn, John (I992) 'On the Myth of Written Constitutions: The Disappearance of Criminal Jury Trial', Harvard Journal of Law \& Public Policy I5: I I 9-I 27.

LANGER, Máximo (2004) 'From Legal Transplants to Legal Translations: The Globalization of Plea Bargaining and the Americanization Thesis in Criminal Procedure', Harvard International Law Journal 45: I-64.

LANGer, Máximo (2006) 'Rethinking Plea Bargaining: Practice and Reform of Prosecutorial Adjudication in U.S. Criminal Procedure', American Journal of Criminal Law 33: 223-299.

LANGER, Máximo (2007) 'Revolution in Latin American Criminal Procedure: Diffusion of Legal Ideas from the Periphery', American Journal of Comparative Law 55: 61 7-676.

MAIER, Julio B.J. (I993) 'Democracia y administración de justicia penal en Iberoamérica: los proyectos para la reforma del sistema penal' in Reformas procesales en América Latina: La oralidad en los procesos. Santiago: Corporación de Promoción Universitaria.

MaLIK, Waleed H. (2007) Judiciary-Led Reforms in Singapore: Framework, Strategies, and Lessons. Washington: The World Bank.

Mather, Lynn (1979) Plea Bargaining or Trial? The Process of Criminal-Case Disposition. Lexington: Lexington Books.

MAURI, Carolina, Rossi, Ivana and soRIA, Patricia (2013) 'Informe sobre la reforma procesal penal en Córdoba', Revista Pensamiento Penal. Available at: 〈http://www.pensamientopenal.com.ar/system/ files/20I4/I2/doctrina35448.pdf> (accessed 6 November 20I7).

MCCOY, Candance (2005) 'Plea Bargaining as Coercion: The Trial Penalty and Plea Bargaining Reform', Criminal Law Quarterly 50: 67-107.

mCleod, Allegra M. (2010) 'Exporting U.S. Criminal Justice’, Yale Law \& Policy Review 29: 83-164. 
mulcahy, Aogan (I994) 'The Justifications of “Justice”: Legal Practitioners' Accounts of Negotiated Case Settlements in Magistrates' Courts', British Journal of Criminology 34: 4I I-430.

palmieri, Gustavo, martínez, María J., LitvachKy, Paula, Aliverti, Ana and HAzÁn, Luciano (2004) Informe sobre el sistema de justicia penal en la Provincia de Buenos Aires. Buenos Aires: CELS.

PRELIMINARY RECITALS LAW NO. II,922 (n.d.) Available at: 〈http://www.gob.gba.gov.ar/legislacion/ legislacion/f-I I922.html> (accessed 6 November 2017).

PRELIMINARY RECITALS LAW NO. 13,183 (n.d.) Available at: <http://www.gob.gba.gov.ar/legislacion/ legislacion/f-I3I83.html (accessed 6 November 20I7).

PROCURACIÓN GENERAL (20I5) 'Fuero criminal y correccional: IPP iniciadas por departamento judicial año 2015'. Available at: 〈https:/www.mpba.gov.ar/files/content/IPP\%20Totales\%2020I5.pdf〉 (accessed 6 November 2017).

REDEX (2010) 'Presentación red de capacitadores en reforma judicial Redex Argentina' in Primer Encuentro Nacional Redex Argentina. Córdoba: Advocatus, I I-I4.

RIEGo, Cristián (2002) 'Informe comparativo: proyecto seguimiento de los procesos de reforma judicial en América Latina', Sistemas judiciales 2: I 2-58.

RiEgo, Cristián and santalices ariztía, Fernando (2003) 'Seguimiento de los procesos de reforma judicial en América Latina: Segundo informe comparativo', Sistemas judiciales 3: 34-78.

ROACH ANLeu, Sharyn and мACK, Kathy (200I) 'Pleading Guilty and Professional Relations in Australia', The Justice System Journal 22: I55-I84.

SAn MARTIn CASTRo, César (I998) 'La reforma del proceso penal peruano', Revista Peruana de Derecho Procesal 2: 227-257.

TIEDE, Lydia B. (20I2) 'Chile’s Criminal Law Reform: Enhancing Defendants' Rights and Citizen Security', Latin American Politics and Society 54: 65-93.

vaRGaS viancos, Juan E. (2003) 'Eficiencia en la justicia', Sistemas judiciales 3: 68-92.

Weigend, Thomas (2006) 'Why Have a Trial When You Can Have a Bargain?' in Antony Duff, Lindsay Farmer, Sandra Marshall and Victor Tadros (eds) The Trial on Trial: Volume 2: Judgement and Calling to Account. Oxford: Hart, 207-222. 